\title{
Synthesis of steroids by echidna (Tachyglossus aculeatus) testis and the effects of gonadotrophin administration
}

\author{
A. R. Bourne* and Magda Weiss \\ Department of Physiology, Monash University, Clayton, Victoria 3168, Australia
}

\begin{abstract}
Summary. After administration of hCG and PMSG to male echidnas (in nonbreeding state) the testis to body weight ratio increased 3 -fold and the diameter of the seminiferous tubules doubled, but spermatogenesis was not induced.

The major conversion product of testicular homogenate with $\left[4-{ }^{14} \mathrm{C}\right]$ progesterone as substrate was $17 \alpha$-hydroxyprogesterone ( $4 \%$ in untreated and $29 \%$ in treated echidnas). Testosterone (5\%), androstenedione (16\%) and $17 \alpha, 20 \beta$-dihydroxypregn4-en-3-one $(7 \%)$ were also obtained in gonadotrophin-treated animals. In untreated animals these steroids were present in minor amounts $(<1 \%)$.
\end{abstract}

\section{Introduction}

Monotremes are the most conservative of the mammals, having affinities with both reptiles and eutherian mammals. The living representatives of the families Ornithorhynchidae (platypus) and Tachyglossidae (echidna) differ from each other in appearance because of their adaptations to different modes of life, but their fundamental organization has probably changed little since early Mesozoic times.

Although it is known that the platypus secretes substantial amounts of testosterone (Carrick \& Cox, 1973) no similar reports are available for the echidna. Under natural conditions echidnas undergo seasonal breeding activity (Griffiths, 1968), but as far as we are aware breeding does not occur in captivity. Male echidnas kept in captivity under conditions of constant temperature and lighting show no evidence of cycles. The testicular size of captive animals is comparable to that found in echidnas taken from the wild during the non-breeding season (E. H. M. Ealey \& W. Johnson, personal communication) and correspondingly spermatogenesis is absent. Female echidnas are also inactive in captivity and do not ovulate (E. H. M. Ealey \& W. Johnson, personal communication).

In eutherian mammals testicular steroidogenesis is largely stimulated by luteinizing hormone (LH), whereas follicle-stimulating hormone (FSH) is required for the control of spermatogenesis (Setchell \& Hinton, 1973). Reptiles, unlike mammals, do not distinguish between these two gonadotrophins and respond to LH or FSH by an increase in steroid production (Tsui \& Licht, 1977).

The work reported here was designed to establish the nature of steroids produced by the testis of the echidna and to determine the effects of LH and FSH administration in vivo on testicular growth and steroidogenesis.

\section{Materials and Methods}

\section{Animals}

Seven male echidnas were used. These animals come under the protection of the Fisheries \& Wildlife Division of the Government of Victoria. The numbers available for experimental

\footnotetext{
* Present address: Biological and Health Sciences, Deakin University, Belmont, Victoria 3216, Australia.
} 
purposes are strictly limited. They were captured in Victoria and kept in the animal house for at least 6 months before the experiments. They were fed on meat meal ( 2 parts), bran (4 parts), glucodin (Glaxo, Australia) (1 part), and a multi-vitamin (Penta-vite, Parke-Davis, Australia) supplement made up with water to semifluid consistency. Drinking water was always available. There was no evidence of breeding activity in these animals while in captivity.

Three untreated animals were anaesthetized with ether and the testes excised. Three animals were treated daily with intramuscular injections of $1250 \mathrm{i} . \mathrm{u}$. human chorionic gonadotrophin (hCG) for 10 days followed by a mixture of 1250 i.u. hCG plus 1000 i.u. pregnant mares' serum gonadotrophin (PMSG) for a further 5 days. The hCG (Primogonyl) and PMSG (Primantron) obtained from Schering (Australia) were administered in physiological saline $(9 \mathrm{~g} \mathrm{NaCl} /$ litre). At the end of the experimental period the testes were removed for study.

One experiment was carried out to show the effect of gonadotrophin treatment within the same animal. The echidna was treated with the hormones in the usual way after which a laparotomy was performed under ether anaesthesia and the left testis was removed and used for incubation studies. The animal was left to recover for 4 months and then the right testis was removed. Monotremes have intra-abdominal testes and castration requires major abdominal surgery, with a high risk of post-operative mortality. We therefore adopted a procedure, which was the reverse of the conventional approach of removing the control testis first, to ensure information on the effect of gonadotrophin.

\section{Incubations}

Testicular tissue was homogenized and incubated in Krebs-Ringer bicarbonate buffer (Umbreit, Burris \& Stauffer, 1964), containing cofactors for generating NADPH, for $1 \mathrm{~h}$ at $37^{\circ} \mathrm{C}$ in an atmosphere of $95 \% \mathrm{O}_{2}: 5 \% \mathrm{CO}_{2}$ (Weiss, 1973). The radioactive substrates were [4$\left.{ }^{14} \mathrm{C}\right]$ progesterone (sp. act. $53 \mathrm{mCi} / \mathrm{mmol}$ ) and $\left[4-{ }^{14} \mathrm{C}\right]$ androstenedione (sp. act. $60 \mathrm{mCi} / \mathrm{mmol}$ ) (New England Nuclear Corp. Pty. Ltd). Radiochemical purity was ascertained by chromatography of each substrate immediately before use. Radioactive substrates $(2 \mu \mathrm{Ci})$ were incubated with $200 \mathrm{mg}$ tissue in a total volume of $5 \mathrm{ml}$. One incubation per substrate was carried out with the testes from each animal.

To account for procedural losses of the major products $100 \mu \mathrm{g}$ androstenedione and $100 \mu \mathrm{g}$ $17 \alpha$-hydroxyprogesterone were added to the incubation mixture before extraction. Losses for conversion products without added carrier were assumed to be the same as for fractions with carrier subjected to similar analytical procedures. The extraction procedures were as previously described (Weiss, 1973).

The following chromatography systems were used: L/80; LB 53/80 (Bush, 1961); thin-layer chromatography (silica gel $G$ ); benzene : ethyl acetate $(3: 1 \mathrm{v} / \mathrm{v})$; and chloroform :acetone $(9: 1$ $\mathrm{v} / \mathrm{v})$. Conversion products were characterized by co-chromatography with authentic steroids (Ikapharm, Israel) both before and after formation of derivatives. Microchemical techniques consisted of acetylation, sodium borohydride reduction and chromic acid oxidation (Weiss, 1973; Bourne \& Seamark, 1978).

Final evidence for radiochemical purity of the formed products was obtained by the ability of the labelled conversion product to form crystals of constant specific activity when mixed with $10 \mathrm{mg}$ authentic inert carriers. Recrystallizations were carried out for the major conversion products, $17 \alpha$-hydroxyprogesterone, androstenedione and testosterone. The specific activities of the last 3 crystallizations did not differ by more than $3 \%$.

\section{Histology}

A sample of testicular tissue was taken from each animal for histological examination. The tissue was fixed in Bouin's fluid and after paraffin-wax embedding, $10 \mu \mathrm{m}$ sections were stained 
with haematoxylin and eosin. Measurements of seminiferous tubule diameter were made by means of an objective micrometer (Olympus, Japan) and a projecting microscope (Micro Promar, Germany). The average diameter of the tubules for each animal was obtained by measuring at least 15 tubules selected at random.

\section{Results}

\section{Testicular weight and seminiferous tubule diameter}

The mean \pm s.e.m. weights of the combined right and left testis in the 3 untreated and 3 gonadotrophin-treated echidnas were $442 \pm 140$ and $1113 \pm 293 \mathrm{mg}$ and the body weights were $3.27 \pm 0.73$ and $2.76 \pm 0.60 \mathrm{~kg}$ in the two groups respectively. The testis to body weight ratios were higher in the treated animals $(P<0.01)$. The mean \pm s.e.m. diameters of the seminiferous tubules in the untreated and gonadotrophin-treated echidnas were $63 \pm 11$ and $109 \pm 10 \mu \mathrm{m}$ respectively $(P<0.01)$. Histological examination of the testes showed no evidence of spermatogenesis in the untreated or gonadotrophin-treated animals. There was no obvious increase in the quantity of interstitial tissue in treated animals.

\section{Incubations}

Six conversion products were isolated when $\left[4-{ }^{14} \mathrm{C}\right]$ progesterone was used as the substrate; they were $17 \alpha$-hydroxyprogesterone, testosterone, androstenedione, 17a,20ß-dihydroxypregn-4en-3-one and $20 \alpha$ - and $20 \beta$-hydroxypregn-4-en-3-one. The percentage yields for the untreated and gonadotrophin-treated animals are given in Table 1.

Table 1. Percentage yield of conversion products (mean \pm s.e.m.) by testicular homogenates from 3 untreated and 3 gonadotrophin-treated echidnas, and an echidna from which the left testis was removed after gonadotrophin treatment and the right 4 months later

\begin{tabular}{|c|c|c|c|c|}
\hline \multirow[b]{2}{*}{ Steroid } & \multirow{2}{*}{$\begin{array}{l}\text { Untreated } \\
\text { animals }\end{array}$} & \multirow{2}{*}{$\begin{array}{l}\text { Gonadotrophin- } \\
\text { treated } \\
\text { animals }\end{array}$} & \multicolumn{2}{|c|}{$\begin{array}{c}\text { Unilaterally } \\
\text { castrated animal }\end{array}$} \\
\hline & & & Left testis & Right testis \\
\hline Testosterone & $0.03 \pm 0.01$ & $4.5 \pm 1.9$ & $7 \cdot 0$ & 0.1 \\
\hline Androstenedione & $0.3 \pm 0.1$ & $15 \cdot 7 \pm 7.5$ & $8 \cdot 2$ & 0.4 \\
\hline 17a-Hydroxyprogesterone & $3 \cdot 8 \pm 2 \cdot 7$ & $28 \cdot 7 \pm 4 \cdot 1$ & $37 \cdot 3$ & $1 \cdot 1$ \\
\hline $\begin{array}{l}\text { 17a,20ß-Dihydroxypregn- } \\
\text { 4-en-3-one }\end{array}$ & $0.2 \pm 0.1$ & $6.6 \pm 0.9$ & $8 \cdot 4$ & $0 \cdot 3$ \\
\hline
\end{tabular}

Untreated animals. The major conversion product from $\left[4-{ }^{14} \mathrm{C}\right]$ progesterone was $17 \alpha-$ hydroxyprogesterone; the yields of 3 other $C_{21}$-steroids, $17 \alpha, 20 \beta$-hydroxypregn-4-en-3-one and $20 \alpha$ - and 20 -hydroxypregn-4-en-3-one and that of androstenedione and testosterone were $<0.5 \%$. Approximately $95 \%$ of the added substrate was recovered unaltered. When the tissue was incubated with $\left[4-{ }^{14} \mathrm{C}\right]$ androstenedione as the substrate, testosterone was the only conversion product isolated in a yield of approximately $10 \%$.

Gonadotrophin-treated animals. There was an overall increase $(P<0.01)$ in steroidogenesis by the echidna testis after gonadotrophin treatment (Table 1). The major product was $17 \alpha-$

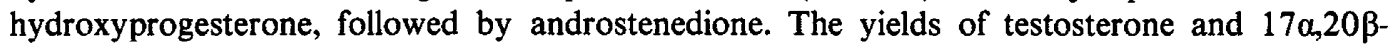
dihydroxypregn-4-en-3-one were considerably higher than in incubations from tissue of untreated animals. The yields of $20 \alpha$ - and $20 \beta$-hydroxypregn-4-en-3-one were less than $1 \%$. 
In the unilaterally castrated echidna the weight of the left testis at removal was $1310 \mathrm{mg}$, while that of the right testis when removed 4 months after was $830 \mathrm{mg}$. The body weight of the animal was $2.76 \mathrm{~kg}$ initially and $2.72 \mathrm{~kg} 4$ months later.

The yields of steroids from the left testis were similar to those of other treated animals (Table 1). After 4 months the effect of gonadotrophin treatment on steroidogenesis was no longer apparent (compare with untreated animals Table 1). The testis weight returned to approximately the size found in untreated animals.

\section{Discussion}

The data indicate that the testicular tissue of echidna was capable of converting [4${ }^{14} \mathrm{C}$ lprogesterone into a spectrum of steroids which was equivalent to that found in eutherian mammals (Eik-Nes, 1970). The yields of individual conversion products, however, varied according to the animal's treatment. The major conversion product from $\left[4-{ }^{14} \mathrm{C}\right]$ progesterone by testes of untreated echidnas was 17 $\alpha$-hydroxyprogesterone while the yields of androstenedione and testosterone were extremely low (Table 1). In the sexually inactive platypus the testosterone production is also low. Carrick \& Cox (1973) reported that in the non-breeding season the concentration in the spermatic vein drops to less than $5 \%$ of that during the breeding season. Our results indicate that the low $\mathrm{C}_{17-20}$ lyase activity in echidna testis may be a limiting factor in the control of androgen production. Since the testosterone yield with $\left[4-{ }^{14} \mathrm{C}\right]$ androstenedione substrate was high, it seems that the $17 \beta$-hydroxysteroid dehydrogenase activity was adequate. A similar accumulation of $17 \alpha$-hydroxyprogesterone in testicular incubates has been obtained for some eutherian species, such as the marmoset (Preslock \& Steinberger, 1977) and rabbit (Matsumoto, Yamada \& Tsujimura, 1976). This is in contrast to data obtained for man (Steinberger et al., 1974), rat (Nayfeh, Barefoot \& Baggett, 1966; Steinberger \& Ficher, 1968; Sowell, Folman \& Eik-Nes, 1974), mouse (Ellis \& Berliner, 1965; Tsujimura \& Matsumoto, 1974) and a marsupial, the possum (Trichosurus vulpecula, unpublished observations), in which testosterone is the primary metabolite formed from incubation of testicular tissue with similar precursors.

In general the phylogenetic specificity of $\mathrm{FSH} / \mathrm{LH}$ to testicular steroidogenesis is related to the source of the testes and the gonadotrophic hormone (Tsui \& Licht, 1977). We succeeded in inducing an increased rate of steroidogenesis in echidnas after 15 days treatment with gonadotrophins of eutherian origin. Although $17 \alpha$-hydroxyprogesterone persisted as the major conversion product, there was an approximately 40 -fold rise in the yields of testosterone and androstenedione (Table 1). Another steroid which increased appreciably was $17 \alpha, 20 \beta$ dihydroxypregn-4-en-3-one. The predominance of the $20 \beta$-hydroxylase over the $20 \alpha$-hydroxylase activity seems to be a characteristic of non-mammalian vertebrates, such as reptiles (Dorfman \& Ungar, 1965; Bourne \& Seamark, 1978).

In addition to an elevated steroidogenic effect, gonadotrophin treatment caused a 3-fold increase in the weight of the testis. It seems likely that the enlargement was mainly due to the increased size of the seminiferous tubules. We did not succeed in inducing spermatogenesis which could have been due to an insufficient duration of treatment, since the relative testicular weights remained in the range which is found in seasonally inactive males (Griffiths, 1968).

The authors are indebted to Dr I. McCance for surgical procedures in the one survival experiment. The echidnas were used with the permission of Fisheries and Wildlife Division of the Government of Victoria. The work was supported by the Australian Research Grants Committee Grant No. D68/16837. 


\section{References}

Bourne, A.R. \& Seamark, R.F. (1978) Seasonal variation in steroid biosynthesis by the testis of the lizard Tiliqua rugosa. Comp. Biochem. Physiol. 59B, 363-368.

Bush, I.E. (1961) The Chromatography of Steroids. Pergamon Press, Oxford.

Carrick, F.N. \& Cox, R.I. (1973) Testosterone concentrations in the spermatic vein plasma of marsupials. J. Reprod. Fert. 32, 338-339.

Dorfman, R.I. \& Ungar, F. (1965) Metabolism of Steroid Hormones. Academic Press, New York.

Eik-Nes, K.B. (1970) Synthesis and secretion of androstenedione and testosterone. In The Androgens of the Testis, pp. 1-39. Ed. K. B. Eik-Nes. Marcel Dekker, Inc., New York.

Ellis, L.C. \& Berliner, D.L. (1965) Sequential biotransformation of 5-pregnenolone- $7 \alpha-{ }^{3} \mathrm{H}$ and progesterone-4- ${ }^{14} \mathrm{C}$ into androgens by mouse testes. Endocrinology 76, 591-599.

Griffiths, M. (1968) Echidnas. Pergamon Press, Oxford.

Matsumoto, K., Yamada, M. \& Tsujimura, T. (1976) Progesterone metabolism in vitro by rabbit testes at different stages of development. Endocrinology 99, 1269-1272.

Nayfeh, S.N., Barefoot, S.W.J. \& Baggett, B. (1966) Metabolism of progesterone by rat testicular homogenates. II. Change with age. Endocrinology 78, 1041-1046.

Preslock, J.P. \& Steinberger, E. (1977) Androgen biosynthesis by marmoset testes in vitro. Gen. comp. Endocr. 31, 101-105.
Setchell, B.P. \& Hinton, B. (1973) Action of gonadotrophins on the testis in mammals. Biblphy Reprod. 21, 817-826; 959-967.

Sowell, Y.G., Folman, Y. \& Eik-Nes, K.B. (1974) Androgen metabolism in rat testicular tissue. Endocrinology 94, 346-353.

Steinberger, E. \& Ficher, M. (1968) Conversion of progesterone to testosterone by testicular tissue at different stages of maturation. Steroids 11, 351368.

Steinberger, E., Smith, K.D., Tcholakian, R.K. Chowdhury, M., Steinberger, A., Ficher, M. \& Paulsen, C.A. (1974) Steroidogenesis in human testes. In Male Fertility and Sterility, pp. 149-174. Eds R. E. Mancini \& L. Martini. Academic Press, New York.

Tsui, H.W. \& Licht, P. (1977) Gonadotrophin regulation in in vitro androgen production by reptilian testes. Gen. comp. Endocr. 31, 422-434.

Tsujimura, A.T. \& Matsumoto, K. (1974) Progesterone metabolism in vitro by mouse testes at different stages of development. Endocrinology 94, 288290.

Umbreit, W.W., Burris, R.H. \& Stauffer, J.F. (1964) Manometric Techniques. Burgers, Minneapolis, Minnestoa.

Weiss, M. (1973) Biosynthesis of adrenocortical steroids by monotremes: echidna (Tachyglossus aculeatus) and platypus (Ornithorhynchus anatinus). J. Endocr. 58, 251-262.

Received 29 August 1978 